Studia z Dziejów Średniowiecza, t. 23, 2019

\author{
Edward Rymar \\ (Instytut Historii i Stosunków Międzynarodowych \\ Uniwersytet Szczeciński, profesor emeritus)
}

\title{
Mściwoj II jako lennik margrabiów brandenburskich (w latach 1269-1273)
}

https://doi.org/10.26881/sds.2019.23.11

Keywords: Duchy of Pomerelia, Magraviate of Brandenburg, fief, homage, Ascanian dynasty, Sobiesławice dynasty

Druga połowa XIII w. to czas rozbudowywania przez margrabiów brandenburskich z dynastii askańskiej nabytków na terytorium wcześniej w całości pomorskim, na wschód od dolnej Odry, na północ od doliny Noteci - dolnej Warty. Młodzi jeszcze, ale dochodzacy do lat sprawnych Jan I i Otton III, synowie zmarłego w 1220 r. margrabiego Albrechta II, otrzymali w grudniu 1231 r. w lenno od Rzeszy Niemieckiej przywilejem cesarza Fryderyka II, wystawionym w Rawennie w obecności książąt Rzeszy, nie tylko wszystkie lenna dziedziczone po ojcu, ale na ich szczególna prośbę, ponadto na dowód szczególnej łaskawości, i obszar „księstwa pomorskiego” (,ducatus Pomeranie”). Oznaczało to przeniesienie na nich zwierzchnictwa lennego nad istniejące tam wtedy podmioty polityczne: księstwa zachodniopomorskie Barnima I (zm. 1278), Warcisława III (zm. 1264), wschodniopomorskie (wtedy: Świętopełka gdańskiego, Sambora II lubiszewskiego, Racibora białogardzkiego, synów Mściwoja I). Margrabiowie uzyskali też prawo zwierzchności nad rywalizującymi z nimi od jakiego czasu ksiązętami wielkopolskimi. Wielkopolscy Piastowie trzymali znaczne obszary pograniczne na północ od Noteci, w zlewniach Drawy, Człapi, Polki, Santocznej, Kłodawki, Myśli, górnej Płoni i górnej Iny (kasztelania santocka, drzeńska, wieleńska). Zwierzchnictwo, które dostali margrabiowie nad Pomorzem, sprawowała wcześniej Polska (po kolejnym podboju za Bolesława 
Krzywoustego i jego pierwszych następców w Krakowie w XII w.), potem na krótko (1185-1210-1223/5) - Dania ${ }^{1}$.

Konsekwentnie od dziesięcioleci wyznaję pogląd, że tytuły prawne do takiego dysponowania terytorium pomorskim państwo niemieckie nabyło (od X w.) jako spadkobierca monarchii frankońskiej na jej wschodzie w IX-X w. ${ }^{2}$ Pogląd o trybutarnej, potem lennej zależności całego Pomorza i to od czasów karolińskich - zasadzający się na wiarogodnym przecież przekazie Einharda w jego Vita Karoli Magni o uzależnieniu w 789 r. przez wielkiego Karola związku Wieletów aż po (dolna) Wisłę - nie spotkał się dotąd z powszechna akceptacją ${ }^{3}$. Do grona oponentów dołączył Błażej Śliwiński, zwłaszcza na nowo obszernie przy okazji swej bardzo cennej monografii księcia wschodniopomorskiego Mściwoja $\mathrm{II}^{4}$. Niniejszy tekst jest próbą dyskusji z niektórymi tezami gdańskiego badacza.

1 E. Rymar, Międzynarodowy kontekst genezy przywileju raweńskiego $w$ sprawie lenna pomorskiego ze szczególnym uwzględnieniem roli arcybiskupa magdeburskiego, „Gdańskie Studia z Dziejów Średniowiecza” 1995, t. 2, s. 137-147; idem, Bolesław Krzywousty, trybutariusz i lennik niemiecki z Pomorza i roztocza odrzańskiego (1135) [w:] Historia lux veritatis, Szczecin 2002, s. 243-267; idem, Wielkie Pomorze obszarem lennym margrabiów brandenburskich $z$ dynastii askańskiej (trybutarnym Rzeszy Niemieckiej), RH 1996, t. 62, s. 21-47; idem, Brandenburgia a Pomorze Gdańskie do poczatków XIV wieku [w:] Rzeź Gdańska $z 1308$ roku w świetle najnowszych badań, red. B. Śliwiński, Gdańsk 2009; idem, Niemiecka Rzesza wobec Polski (Pomorza Gdańskiego i Stawieńsko-Stupskiego) pod Przemyślidami w latach 1300-1306, „Studia Historica Slavo-Germanica” 1987, t. 16, s. 37-68; idem, O prawach Królestwa Niemieckiego i Marchii Brandenburskiej do zwierzchnictwa nad catym Pomorzem, RH 2006, t. 72, s. 7-51.

2 E. Rymar, Karolińska geneza trybutarnego stosunku władców Polski do królów niemieckich (X-XIII w.), CPH 1989, t. 41, s. 1-34. W nurcie wywodu pozostaja (ale w odniesieniu do terytorium Ślasska) idem, O genezie powstania i przyczynach upadku państwa wielkomorawskiego - inaczej, „Slavia Antiqua” 1989/1990, t. 32, s. 93-128; idem, Prawnopolityczny stosunek Kazimierza Odnowiciela do Niemiec oraz termin odzyskania przez niego Ślaska (1041 r.), „Ślaski Kwartalnik Historyczny. Sobótka” 1987, t. 42, s. 137-170 i inne „ślaskie” rozprawy.

3 J. Spors, Rzekome tytuty prawne Brandenburgii do Pomorza Gdańskiego opierajace się na potwierdzeniach z 1231 i $1295 \mathrm{r}$. [w:] Personae, colligationes, facta. Profesorowi Kazimierzowi Jasińskiemu w 70. rocznicę urodzin, Toruń 1991, s. 240 et seq.; G. Labuda, Podstawy polityczno-prawne kupna Pomorza Gdańskiego przez zakon krzyżacki od margrabiów brandenburskich w latach 1309-1310, RH 2005, t. 71, s. 31-60; idem, O zakresie rzekomych uprawnień Królestwa Niemieckiego i Marchii Brandenburskiej nad catym Pomorzem we wczesnym średniowieczu, RH 2007, t. 73, s. 17-34. Inaczej dopiero wrocławski historyk prawa prof. T. Kruszewski, Rodowód pierwszych Piastów wielkopolskich (potomstwo Mieszka III Starego i jego synów) na tle rodowodu ksiażat pomorskich. Studium historycznoprawne i genealogiczne, Wrocław 2017, s. 47 et seq.

4 B. Śliwiński, Mściwoj II (1224-1294), ksiażę wschodniopomorski (gdański), Warszawa 2016, s. 20 et seq. 
Margrabiowie po 1231 r., wraz z parciem na wschód i ku Bałtykowi na terytorium pomorskim, najpierw uzależnili w sposób lenny Gryfitów (Warcisława III w 1236 r., Barnima I w 1235-1236 r. i 1250 r.), pozostawiając ich przy pomorskim władztwie, wszak za cenę sporych cesji terytorialnych w obszarach na zachód od dolnej Odry. Po 1250 r. sadowili się w prawobrzeżnej (tzn. w części pomorskiej, na północ od dolnej Noteci - Warty) kasztelanii santockiej, zyskując wsparcie czy aprobatę marionetkowego króla niemieckiego Wilhelma (1247-1256). Kiedy Piastowie wielkopolscy złożyli (1253 r.) z tego powodu skargę do Stolicy Apostolskiej na margrabiów i króla Wilhelma, to w ramach ustępstwa - bo nie wchodził w rachubę hołd Piasta poznańskiego - ubrano brandenburski zabór w postać posagu księżniczki wielkopolskiej Konstancji wydawanej za krewniaka, margrabica Konrada (syna Jana I), przy czym na prośbę owego króla papież zlecił udzielenie dyspensy z powodu pokrewieństwa młodych (1255 r.). Potem Askańczycy rugowali czy ograniczali w ich stanie posiadania konwenty templariuszy (1262 r. pozostawiono im komandorię chwarszczańska, przejmując komandorię myśliborską i ich kilka wsi przy drodze z Kostrzyna do tworzonego od 1257 r. miasta Nowego Landsberga/Gorzowa); joannitów (zlikwidowano komandorię korytowska, ograniczając ich do parafii w Choszcznie); nawet cystersów kołbackich, bo wypędzono (1269 r.) ich z dworu (grangii?) Sowno pod Choszcznem. W tworzonej w ten sposób ziemi zaodrzańskiej (,terra transoderana”) ograniczono też biskupów - władców terytorialnych. Od swego biskupa brandenburskiego przez zamianę Askańczycy nabyli ziemię Königsberg/chojeńska (1267-1270), od biskupa kamieńskiego Hermana von Gleichen wykupili ziemię lipiańską (1276 r.), a także nabyli świdwińską i pełczycka (1280 r.). Sygnalizuję tu jedynie proces i sposoby realizowania przez margrabiów przywileju raweńskiego, odsyłając czytelnika zainteresowanego szczegółami i dokumentacją do stosownej literatury ${ }^{5}$, by już przechodzić do meritum. Bo następnym etapem - czytelnym od 1269 r. - było rozciaganie zwierzchnictwa margrabiów nad Pomorzem Środkowym i Wschodnim, gdzie w międzyczasie dochodziło po 1266 r. (zgon Świętopełka gdańskiego) do sprzyjającego ich poczynaniom zakończenia rozdrobnienia dzielnicowego.

5 O nabytkach w ziemi zaodrzańskiej i ich legalizowaniu zob. szerzej E. Rymar, Historia polityczna i społeczna Nowej Marchii w średniowieczu (do roku 1535), Gorzów Wielkopolski 2015, s. 153-184. 
By się zbytnio nie powtarzać, podejmę dyskusję tylko z niektórymi poglądami Autora wspomnianej książki, wyrażonymi przy okazji omawiania trzech źródeł i trzech momentów politycznych w stosunkach Mściwoja z Askańczykami brandenburskimi z linii starszej:

1. hołd choszczeński (1 kwietnia 1269 r.),

2. list Mściwoja do margrabiów z ofertą w sprawie ziemi gdańskiej (1271 r.),

3. układ drawski (nad rzeką Drawa) Mściwoja z margrabiami (3 września 1273 r.).

\section{Układ choszczeński (1 kwietnia 1269 r.)}

Mściwoj II, jeszcze jako dzielnicowy książę w południowej połaci Pomorza Nadwiślańskiego z ośrodkiem w Świeciu nad Wisła, zawarł 1 kwietnia 1269 r. z margrabiami linii joannickiej: Janem II, Ottonem IV i Konradem układ w Arnswalde/Choszcznie polegający na tym, że margrabiowie wydadzą za mąz córkę Mściwoja, przy czym on da córce 1000 grzywien srebra tytułem posagu, a jej mąż będzie dożywotnio corocznie płacić 100 grzywien. Na znak przymierza Mściwoj II zrzekł się również wszystkich swych dóbr (posiadłości) na rzecz margrabiów, „swych panów” (trzykrotnie określa ich: „dominis nostris”), przejmując je z powrotem, ale już jako lenno (,złożywszy im hołd, jak się prawnie należy”). Dobra te potem mieli posiadać żona i dzieci księcia pomorskiego, jednak za wyjątkiem grodu „Belgart” wraz z przynależną doń ziemią. Ziemię tę margrabiowie mieli przejąć na swój wyłączny użytek, ale w zamian za coroczną wypłatę Mściwojowi, jego żonie i dzieciom (,pueri”) 100 stendalskich grzywien srebra lub dostarczenie 100 korców zboża (30 pszenicy, 40 żyta, 30 jęczmienia). Dokument - znany jedynie z kopiariusza brandenburskiego - kończy się zapewnieniem udzielenia margrabiom pomocy przeciw każdemu, przywieszeniem pieczęci i lista świadków wywodzacych się tylko z otoczenia księcia. Byli to: „Zistlaw, Domezlaw, Dalez, Pozewalc, Mizlebor, Peter, Nicolaus, Koyt”“ . Świadkowie ci występowali przy czynnościach prawnych Mściwoja II jako księcia Świecia (dwaj pierwsi to kapelani, pozostali urzędnicy dworscy). Z postanowieniami układu w Choszcznie wiąże się notę zredagowaną w cysterskim klasztorze położonym w ziemi sławieńskiej Bukowie Morskim. Wspomniano w niej o tym, jak to w okresie drożyzny

6 PrUB, Bd. 2, nr 880. 
margrabiowie dostarczali Mściwojowi złoto, srebro, kosztowne tkaniny, ale i mnóstwo zboża przewożonego morzem do Darłowa, w czego wyniku książę zgodził się uznać ich swymi sukcesorami ${ }^{7}$.

Dokument układu w Choszcznie znany jest przede z odpisu z oryginału z archiwum w Szwerynie. Historycy traktuja go powszechnie jako akt hołdowniczy. Dokument ten nie zawiera wyraźnego śladu obecności margrabiów w Choszcznie, ale też niczego, co by ich pobyt wykluczało ${ }^{8}$. Co więcej, poniżej znajdziemy wskazówki źródłowe mogace przemawiać za faktyczną obecnościa w Choszcznie. Podnoszę tę kwestię tylko dlatego, że w analogiczny sposób i „opakowaniu” powstał akt hołdowniczy Mściwoja w 1273 r. na moście na Drawie, o czym w stosownym miejscu. Mimo wskazanej analogii układ drawski został zupełnie inaczej zinterpretowany przez Śliwińskiego, do czego też poniżej dotrzemy. Pomimo wątpliwości co do bytności margrabiów w Choszcznie, obecnie bierze się już pod uwagę możliwość, czy nawet pewność udziału w zjeździe choszczeńskim Mściwojowego kuzyna: Barnima I zachodniopomorskiego i biskupa kamieńskiego Hermana. Już bowiem 7 kwietnia obydwaj, a także szwagier Mściwoja (mąż córki księcia Świętopełka) powiązany z biskupem, Henryk hrabia Kirchberg, przebywali w Skalinie opodal Stargardu, skąd udali się do Szczecina (gdzie byli 11 kwietnia) ${ }^{9}$. Mogli więc powracać ze spotkania w Choszcznie, a co najmniej w obliczu tych podejrzanych kontaktów Mściwoja z margrabiami, byli w pobliżu objętego w 1269 r. konfliktem zbrojnym swego pogranicza z nabytkami pomorskimi margrabiów $^{10}$. Bo przecież Barnim, jego niemieckie rycerstwo lenne, także cystersi kołbaccy, zagarnęli właśnie tereny joannitów korytowskich w okolicy Choszczna i Recza, co naraziło ich na klątwę kościelna,

7 SRP, Bd. 1, s. 773; B. Śliwiński, Mściwoj II..., s. 120. Związek genetyczny informacji bukowskiej z układem choszczeńskim uznałem za możliwy w rozprawie E. Rymar, Walka o Pomorze Gdańskie w latach 1269-1272, RG 1987, t. 47, s. 24 et seq.

8 Na brak podstaw do wykluczania obecności margrabiów w Choszcznie zwracał uwagę już H. Krabbo w: Regesten, Bd. 1, uwaga do nr 969.

9 PUB, Bd. 2, nr 881, 882. O ich powrocie z Choszczna E. Rymar, Henryk hrabia Kirchberg, szwagier Mściwoja II pomorskiego, ZH 1983, t. 48, s. 192; idem, Cystersi na terytorium Nowej Marchii przed $i$ w trakcie jej tworzenia oraz ich stosunki $z$ margrabiami z dynastii askańskiej [w:] Historia i kultura cystersów w dawnej Polsce, red. J. Strzelczyk, Poznań 1987, s. 201; idem, Wtadcy Brandenburgii na dzisiejszych ziemiach polskich, zwłaszcza w Nowej Marchii i na Pomorzu w latach 1200-1319 (itinerarium), wyd. 1, „Rocznik Słupski” 1988/89, s. 48; wyd. 2, „Nadwarciański Rocznik Historyczno-Archiwalny” 2008, t. 15, s. 24.

10 Rozważał to również B. Śliwiński, Mściwoj II..., s. 118, ale możliwość taka wykluczył. 
interwencję papieska. I w tych to okolicznościach margrabiowie w 1269 r. wypędzili cystersów z ich dworu w Sownie pod Choszcznem, najwyraźniej od tej pory okupując ten obszar z pomocą tych rodów rycerskich, zwłaszcza Wedlów ${ }^{11}$.

Chcac zaprezentować interpretację aktu choszczeńskiego, inna niż przedstawiona przez Śliwińskiego, zwrócę jeszcze uwagę na treść wspomnianego już dokumentu ze Skalina z 7 kwietnia 1269 r. Wynika z niego, że rycerz Konrad von Kleist oświadczył w obecności księcia Barnima I i biskupa Hermana, przywołując też ich pieczęcie, a na świadków powołując również Henryka hrabiego Kirchberg, rycerza Anzelma von Blankenburg „i wielu innych”, że w intencji zbawienia zmarłego brata swego Bertolda przekazuje cystersom z Kołbacza po swej śmierci wieś Bielice, otrzymaną od Świętobora Świętoborzyca (zatem zapewne w latach 1220-1242?) ${ }^{12}$. Oddaje dalej cystersom miejsce po wsi Brody nad Płonią (opodal jej ujścia do jeziora Miedwie) i 4 łany (więc chyba kościelne czy raczej sołtysie) w Obrytej i Zaborsku (również wsie cysterskie od dawna; obecnie w gminie Warnice ${ }^{13}$. Kim był ten rycerz i skąd tak wielka jego właśnie w tym momencie cesja na rzecz cystersów?

Konrad jest pierwszym znanym przedstawicielem rodu pomorskiego von Kleist. Przybył na Pomorze z bratem Bertoldem ze Starej Marchii zapewne w latach 1230-1240 ${ }^{14}$, może przez Meklemburgię, gdzie stwierdzono las tego miana. Konrad był marszałkiem dworu księcia Barnima I, często testując jego dokumenty w latach (1240) 1248-1254 $4^{15}$. W 1254 r. Barnim I przeniósł na cystersów kołbackich 60 łanów we wsi (więc całej, bo tyle zwykle posiadały na prawie niemieckim) „Lucowe, Zedeliz”, z których zrezygnowali rycerze bracia Bertold

11 E. Rymar, Historia polityczna..., s. 178 et seq. (tam ważniejsza literatura).

12 Chodzi o Świętobora II Świętoborzyca syna Kazimierza (I) znanego z lat 1219-1244, zob. E. Rymar, Rodowód ksiażat pomorskich, wyd. 2, Szczecin 2005, s. 194.

13 PUB, Bd. 2, nr 881.

14 Tak za L. Quandt'em G. Kratz, Geschichte des Geschlechts von Kleist, Bd. 1: Urkundenbuch, Berlin 1862.

15 PUB, Bd. 1, nr 470: 1248 r. (po rycerzach i Dytryku Bawarze), nr 476: 1248 r. w Pyrzycach przy fundacji klasztoru w Marianowie jako marszałek, nr 484: $1249 \mathrm{r}$. przy nadaniu dla Szczecina, nr 485: (1240?) 1249 r. przy fundacji miasta Gardźca na końcu listy rycerzy, nr 517: 1250 r. przy nadaniu dla pyrzyckiej parafii, nr 527, 543: 1251 r., nr 554, 555: 1252 r. przy nadaniu dla cysterek szczecińskich dóbr kupionych w ziemi widuchowskiej, nr 566, 572, 577: 1253 r. et seq.: w 1254 w Żelewie przy nadaniu Barnima I dla cystersów z Kołbacza; Bd. 2 nr 599: 1259 przy regulowaniu granic ziemi lipiańskiej biskupa Hermana z pyrzycką Barnima, nr 667; z bratem w 1249 r. w Kołbaczu, PUB, Bd. 1, nr 494. 
i Konrad Kleistowie ${ }^{16}$.To późniejszy Kierzków (1295 r.) k. Trzcińska ${ }^{17}$. Konrad miał dom w Szczecinie. Znika z pomorskich źródeł Barnima po 1259 r., choć niekiedy sądzono, że pozostawał w związku z dworem Barnima I jeszcze do $1263 \mathrm{r} .{ }^{18}$ Powodem tego przypuszczenia był fakt, że wspomniany książę 8 lipca 1263 r. fundował kolegiatę NMP w Szczecinie w obszarze swego byłego grodu i dworu, ale też byłego (,quondam”) dworu rycerza Konrada von Kleist ${ }^{19}$. Konrad przeniósł się już wówczas do Brandenburgii. Dnia 2 lutego 1267 r. był obecny we wkrzańskim Stolpe przy potwierdzaniu przez margrabiów klasztorowi w Parstein dóbr $\mathrm{w}$ granicach ustalonych przez komisję z jego udziałem ${ }^{20}$. Spotkamy się z nim jeszcze poniżej i to w związku z podobną czynnościa Mściwoja II na rzecz margrabiów, stąd nasze nim zainteresowanie.

Konrad von Kleist, będąc już człowiekiem margrabiów, udał się z księciem pomorskim i biskupem kamieńskim w drogę powrotną z Choszczna. Mógł też zostać wysłany przez Askańczyków z Choszczna do pomorskiego księcia i biskupa kamieńskiego. Von Kleist doścignał ich w Skalinie, w drodze do Szczecina. Po spotkaniu z nimi zajął się tak hojnym obdarowaniem cystersów. Kto wie, czy nie wykonywał jakiejśs misji margrabiów, by pomóc w załagodzeniu ich świeżego konfliktu z cystersami. A wiemy, że wdzierstwo Askańczyków nie objęło tylko samego dworu klasztornego w Sownie pod miastem, ale też rozległy kompleks dóbr cysterskich nad Małą Iną (dziś w gminie Dolice), z nadania Władysława Odonica wielkopolskiego (w latach 1232-1236) wokół Dobropola, Warszyna, opuszczonego potem „Trzebienia” (koło Dolic) ${ }^{21}$. Może należy też zwrócić uwagę na najważniejszego obok księcia i biskupa świadka czynności, rycerza Anzelma z Blankenburga?

Jego przodkowie to ród ministeriałów w górach Harzu, w związku z Blankenburgiem na zachód od Kwedlinburga, zwany początkowo „de Campe”. Blankenburgowie pełnili funkcje urzędnicze przy hrabiach Blankenburga, książętach Brunszwiku, biskupach z Hildesheim, podobnie jak panowie Borneke czy Bornstede, którzy równiė̇

16 PUB, Bd. 2, nr 590.

17 E. Rymar, Historia polityczna..., s. 138, 164; a zwłaszcza idem, Stownik historyczny Nowej Marchii w średniowieczu, t. 3: Ziemia lipiańska, myśliborska, golenicka, gorzowska, pełczycka (w druku, hasło Kierzków).

18 K. Guzikowski, Obce rycerstwo na Pomorzu Zachodnim do poczatku XIV wieku, Szczecin 2013, s. 226.

19 PUB, Bd. 2, nr 740.

20 CDBrand. A, Bd. 13, s. 211.

21 E. Rymar, Historia polityczna..., s. 122 et seq., 178, 187. 
po 1230 r. przenieśli się do księstwa pomorskiego (ich ośrodkiem był zamek Ramlewo w ziemi kołobrzeskiej) ${ }^{22}$. Jordan, kanonik w Hildesheim, w 1257 r. wystapił przy czynności biskupa kamieńskiego Hermana, w 1260 r. znów przebywał w Hildesheim. Brat Jordana, Anzelm, obecny przy nadaniu praw miejskich Szczecinowi (1243 r.). $\mathrm{Z}$ pewnością trzeba go utożsamić ze znanym z dokumentów z lat 1244, 1254 rycerzem Anzelmem z położnego w ziemi kołbackiej Chabowa (dziś gmina Bielice). Anzelm posiadał tę wieś z 60 łanami, podobnie jak Kleist z nadania Świętobora Świętoborzyca, a więc musiał ją otrzymać przed 1242 r., co też później zalegalizował Barnim I. Anzelm był członkiem książęcej załogi grodu w Pyrzycach, gdzie miał dwór na podgrodziu, o czym wzmiankowano dopiero w 1279 r., gdy dwór nadano tamtejszym zakonnicom, a jego wraz z dziedzicami nazywano wtedy dawnym (,quondam”) posiadaczem. On i brat Jan (1260 r.) byli przodkami linii pomorskiej, nowomarchijskiej i wkrzańskiej (tu wieś Blankenburg koło Prenzlau, 1250 r.) ${ }^{23}$. Podobnie jak Kleistów braci Anzelma i Jana von Blankenburgów spotykamy od 30 kwietnia 1266 r. przy czynnościach margrabiów joannickich ${ }^{24}$. Zapewne to już synowie Anzelma - Jan (II) i Anzelm (II) - znani od schyłku XIII w., wysługiwali się margrabiom w ich poczynaniach na wschodzie, zapewne jak wspomniani wyżej Wedlowie, mając od około 1269 r. lenno w okolicy Recza. Tak więc i Anzelm był w Skalinie w misji von Kleista jako podobnie stary znajomy księcia i biskupa, obecnie w służbie margrabiów linii starszej. To nie mogło być przypadkowe!

Domysł o ewentualnym pobycie Barnima w Choszcznie wzmocniono jego spotkaniem z Askańczykami, jego panami lennymi, w Gerswalde, gdzie ci zatwierdzali szczecińską fundacje mariacka Barnima I, określając księcia powinowatym (,gener”), jako że ten był już wtedy w trzecim związku małżeńskim z margrabianką Matylda. A działo się to 12 stycznia 1269 r., w okresie awantury wywołanej zajęciem dóbr joannitów korytowskich wokół Choszczna i Recza, również w obecności właśnie znanych nam osób: biskupa kamieńskiego Hermana, Henryka hrabiego von Kirchberg, Anzelma von

22 E. Sauer, Der Adel während der Besiedlung Ostpommerns (der Länder Kolberg, Belgard, Schlawe, Stolp) 1250-1350, Stettin 1939, s. 107 et seq.

23 PUB, Bd. 2, nr 599: 1254 r., nr 1136: 1279 r.; F. Streng, Umgebung und Herkunft der Knappen de Borneke, de Velthane und de Locstede, Partner im Vergleich um die Fischereirechte am Woltiner See im Jahre 1302, BS NF, 1980, Bd. 66, s. 14 et seq.

24 Regesten, Bd. 1, nr 916; CDBrand. A, Bd. 13, s, 211; CDBrand. B, Bd. 1, s. 94; CDBrand. A, Bd. 23, s. 5; Bd. 13, s. 319; Bd. 7, s. 201 et seq. 
Blankenburg, Konrada von Kleist ${ }^{25}$. To bowiem Barnim mógł zachęcić kuzyna do obrania opcji brandenburskiej w obliczu spodziewanej konfrontacji z gdańskim bratem Warcisławem $\mathrm{II}^{26}$.

Nie to jednak jest najważniejsze, ale osobliwa treść hołdowniczego aktu z Choszczna.

Jak to zinterpretować? Obecnie największym uznaniem cieszył się pogląd Gerarda Labudy, że to najosobliwszy z układów lennych na Pomo$\mathrm{rzu}^{27}$. Zwłaszcza ową pozorną „osobliwością" trzeba będzie się zająć.

Śliwiński opinię takową tłumaczy fałszywym dotąd objaśnianiem przekazu. Już to przez wytypowanie Białogardu nad Parsęta, bo od 1280 r. panem tego grodu i ziemi był książę Przybysław II, zwany pieszczotliwie „Przybkiem”, wygnaniec meklemburski, mąż Katarzyny, córki Mściwoja II. Uznano więc, że już w 1269 r. zapowiedziano to małżeństwo, przy czym stadło miało zostać uposażone w Białogardzie. Sądzono, że Mściwoj przekazał gród margrabiom, a ci wydali go swemu klientowi, Przybkowi ${ }^{28}$. Ale - nadal wedle Śliwińskiego - wykazano już przed nim wcześniej, że w tym Białogardzie książęta wschodniopomorscy nigdy nie panowali i nie mieli do niego tytułów prawnych, a Przybysław otrzymał go dopiero po 1278 r. (zgon Barnima I) z łaski jego syna Bogusława IV! ${ }^{29}$, zatem była to Białogarda nad Łeba, w księstwie wschodniopomorskim, wcześniej gród Racibora stryja Mściwoja $\mathrm{II}^{30}$. Temat grodu Białogard pozostawmy jednak na boku, bo nie to jest osobliwe. Ważniejsza jest odpowiedź na pytanie, przeciwko komu był akt choszczeński wymierzony i dlaczego Mściwoj posunął się do zawiązania stosunku lennego wobec margrabiów.

25 PUB, Bd. 2, nr 876.

26 B. Śliwiński, Mściwoj II..., s. 117.

27 G. Labuda [w:] Historia Pomorza, t. I/1, Poznań 1972, s. 530; B. Śliwiński, Mściwoj II..., s. 119 et seq. daje przegląd wcześniejszych opinii i interpretacji.

28 R. Klempin [w:] PUB, Bd. 1, s. 193; G. Kratz, Die Städte der Provinz Pommern, Berlin 1865, s. 33, E. Sauer, Der Adel..., s. 116, P. v. Niessen, Geschichte der Neumark im Zeitalter ihrer Entstehung und Besiedlung (von den ältesten Zeiten bis zum Aussterben des Askanier, Landsberg 1905, s. 218 et seq.; J. Schultze, Die Mark Brandenburg, Bd. 1, Berlin 1961, s. 178; P. Czaplewski, Tytulatura ksiażat pomorskich, ZH 1949, t. 15, s. 38; K. Zielińska, Zjednoczenie Pomorza Gdańskiego z Wielkopolska pod koniec XIII w. Umowa kęińska 1282 r. Toruń 1968, s. 21; i liczni inni.

29 O czym J. Spors, Dzieje polityczne ziem stupskiej, sławieńskiej i białogardzkiej XII-XIV w., Poznań-Słupsk 1973, s. 128 et seq.

30 G. Labuda, Marginalne uwagi o dziejach Pomorza Stawieńsko-Stupskiego w XII i XIII w., ZH 1977, t. 42, s. 97. 
Ta obecność Barnima I w Skalinie pod Stargardem tydzień po spotkaniu choszczeńskim posłużyła Śliwińskiemu do budowania narracji, że to nie w niego był wymierzony akt choszczeński. Sądzono, że widocznie układ kamieński z 1264 r., którym Mściwoj, wtedy tylko książę na Świeciu, czynił kuzyna Barnima swym sukcesorem, był już zerwany, zresztą w 1266 r. Barnim podjął zbrojną próbę wydarcia swemu bratu Warcisławowi II ziemi sławieńskiej ${ }^{31}$. Ponieważ bracia Sobiesławice zgodnie próbowali ziemię tę odzyskać w 1268 r., poczęto ostrza aktu choszczeńskiego i przeciw Warcisławowi II się dopatrywać, zwłaszcza że wnet doszło do wojny domowej między braćmi ${ }^{32}$. Obecnie już dominuje koncepcja, iż przyczyną aktu był Barnim, a bezprawne dysponowanie Białogardem nad Parsętą miało być rewanżem na nim za zabór ziemi sławieńskiej, odzyskanej z pomocą margrabiów - przy tej okazji widocznie zdobyto i białogardzka. Tyle że badacze snujący taki przebieg zdarzeń nie wiedzieli jeszcze, że Barnim ewentualnie brał udział w zjeździe choszczeńskim, w jego obecności spisano akt hołdowniczy, na co zwróciłem uwagę dopiero w latach osiemdziesiątych XX w.

Śliwiński, traktując już przeto udział Barnima w spotkaniu choszczeńskim jako rzecz pewna, do czego i ja skłaniam się nie tak stanowczo jak dawniej ${ }^{33} \mathrm{w}$ konsekwencji uznał, że układ nie mógł być w niego wymierzony, postanowienia kamieńskie zaś obowiązywały i nie były w Choszcznie naruszone. Skoro zgodnie z hołdem landyńskim z 1250 r. Barnim, lennik margrabiów, uzyskał ekspektatywę na dziedziczenie księstwa po kuzynie - moim jednak zdaniem dodatkowo - także ich lenniku Warcisławie III Dymińskim, co sprawia, że margrabiowie w chwili

31 Tak już F.W. Barthold, Geschichte von Rügen und Pommern, Hamburg 1840-1842, Bd. 2, s. 534; E. Długopolski, Władysław Łokietek na tle swoich czasów, Wrocław 1951, s. 36; K. Jasiński, Zapis Pomorza Gdańskiego przez Mszczuja w roku 1282, „Przegląd Zachodni” 1956, t. 8, s. 180; J. Powierski, Układ kamieński na tle stosunków między ksiażętami Pomorza, Krzyżakami i Prusami w latach sześćdziesiatych XIII wieku, „Rocznik Olsztyński” 1968, t. 8, s. 28; J. Spors, Dzieje..., s. 120, E. Rymar, Walka..., s. 12. Pogląd ten opisuje i falsyfikuje B. Śliwiński, Mściwoj II..., s. 122 .

32 E. Sauer, Der Adel..., s. 115; P. Czaplewski, Tytulatura..., s. 39; K. Jasiński, Zapis..., s. 180; K. Zielińska, Zjednoczenie..., s. 21; B. Włodarski, Świętopełk i Mściwoj II, ZH 1968, t. 33, s. 82; E. Rymar, Okolice Pyrzyc i Stargardu w okresie wzmożonej agresji brandenburskiej na Pomorzu w II połowie XIII w., „Zeszyty Pyrzyckie" 1969, t. 2, s. 91; idem, Wielkie Pomorze..., s. 35 et seq.; idem, Brandenburgia a Pomorze Gdańskie do poczatków XIV wieku..., s. 51.

33 Chodzi o moje rozprawy: Henryk hr. Kirchberg..., 1983, s. 192; Cystersi na terytorium..., s. 201; Władcy Brandenburgii..., wyd. 1, s. 48, 
jego zgonu w 1264 r. nie przejęli jego księstwa, to „trudno nawet więc przypuszczać, by w okresie rozmów w Choszcznie władcy brandenburscy nie zostali zobligowani do identycznego potraktowania wcześniejszych układów Barnima I i Mściwoja II”. Badacz w sposób, jak się obecnie wydaje, ostateczny wykazał, że w omawianym akcie hołdowniczym mowa nie o trzymanym wtedy i potem do około $1286 \mathrm{r}$. przez książąt zachodniopomorskich Białogardzie nad Parsęta, lecz Białogardzie nad Łeba, przekazanym wraz z ziemią testamentem przez księcia Racibora Krzyżakom. Przekazanie księstwa białogardzkiego, do którego Mściwoj miał prawo ze stryjem Samborem II i bratem Warcisławem, było widocznie próbą przeciwstawienia margrabiów zakonowi. „I taki byłby sens układu choszczeńskiego”, dodatkowo w 1269 r. Mściwoj złożył hołd z księstwa świeckiego, nie zaś z całego Pomorza Wschodniego, bo to byłoby od strony prawnej wykluczone, jako że żyli na jego częściach inni władcy - konkluduje badacz gdański. Gromadzi też zaraz argumenty przemawiajace za posiadaniem zgody Warcisława na takie rozporządzanie ziemią białogardzką. Trafnie i słusznie wyklucza przy tym, że układ choszczeński był aktem wrogości Mściwoja II względem brata Warcisława II i Barnima ${ }^{34}$.

W konkluzji, układ w Choszcznie miał być tylko elementem szeroko zakrojonych działań dyplomatycznych Mściwoja o ostrzu antykrzyżackim, z zaangażowaniem brata, kuzyna ze Szczecina i margrabiów. Śliwiński ostatecznie dostrzegł takie oto zyski uczestników gry dyplomatycznej Mściwoja:

- Mściwoj: zyskiwał w margrabiach sojusznika w kwestii ziemi białogardzkiej;

- Warcisław II: wprowadził szwagra Henryka hr. Kirchberg do zachodniej ziemi sławieńskiej oraz zyskiwał pokój i życzliwość biskupa Hermana;

- Margrabiowie: uzyskali lenne zwierzchnictwo nad Mściwojem i możliwość przejęcia Białogardy;

- Barnim: zyskał dalszą możliwość pokojowego następstwa po Mściwoju i utrzymanie władzy w ziemi sławieńskiej (nad uposażonymi w niej Kirchbergiem i Przybkiem księciem „bez ziemi”, wygnańcem meklemburskim) ${ }^{35}$.

Ale nie wszystkie te plany wcielono w życie, bo wybuchła wojna domowa Mściwoja z bratem.

34 B. Śliwiński, Mściwoj II..., s. 126 et seq.

35 Ibidem, s. 131 et seq. 
Inne szczegółowe kwestie rozważane przez Śliwińskiego w związu z układem w Choszcznie (jak: losy ziemi sławieńskiej, białogardzkiej nad Parsęta, Przybysławów meklemburskich uposażonych w Wolinie i Białogardzie; realizacja planu małżeńskiego Henryka hrabiego Kirchberg, usadowionego w zachodniej części ziemi sławieńskiej, z siostrą Mściwoja) - można komentować przy innych okazjach.

Jeśli nawet Śliwiński ma liczne cenne spostrzeżenia i konstatacje, to jednak nie dotyczą one owej osobliwości układu choszczeńskiego, dostrzeganej przez badaczy (jak Labuda). Przecież książę udał się znad Wisły 200 km na zachód, by zdeklarować oddanie swego kraju w lenno niemieckim władcom terytorialnym i to - gdy przyjmiemy punkt widzenia badacza - o ostrzu antyniemieckim, bo godzącym z zakon krzyżacki! Przecież książę nie był przez margrabiów zagrożony, wybrał ich sobie na sojuszników, ale jednak aż za tak wysoką cenę. Po co bowiem rezygnować z suwerenności, skoro był on bezpieczny nad Wisłą? Po co mu to było? Dla zdobycia Białogardy nad Łeba? Nie do wiary! Czy nie mógłby takiego celu osiagać wraz z Barnimem, szwagrem i bratem, a nawet kuzynem wielkopolskim?

Inaczej się rzecz ma, gdy stajemy na gruncie uprawnień zwierzchniczych margrabiów. Trzykrotnie Mściwoj określa ich „swymi panami” (,dominis nostris”), przekazał im swe ziemie i wzią je z powrotem, ale już jako lenno, złożywszy im hołd, który im się „prawnie należał” (,in feudum, homagium ipsis, prout iustum est”). Dla mnie to jest najważniejsze, a nie tylko roztrząsanie kwestii książęcych motywów i zysków. Bo oto kolejny podmiot na Pomorzu, to nic, że dla wyniesienia korzyści, bo wszak nie mogło być inaczej, skoro nie znalazł się pod ich presja, staje na gruncie tytułów prawnych Askańczyków. Zrobił to - być może pod wpływem księcia Barnima i biskupa Hermana, gdy już wstępując do Choszczna, traktował margrabiów jako swych zwierzchników z mocy niemieckiego prawa. Pozostawali nimi z mocy tego prawa również wcześniej, gdy Mściwoj hołdu nie składał! Wynosili jednak ową wspomnianą wyżej korzyść, gdyż kolejny książę stanął na gruncie ich przywileju z 1231 r. Była zgoda na ich zgodę na regulację kamieńska z 1264 r. pomiędzy ich lennikami, Barnimem i Mściwojem, ale nie było zgody na zobligowanie margrabiów do takiej zgody. U nich, posiadających lenne zwierzchnictwo nad Pomorzem, ksiązęta jakoby o taką zgodę winni zabiegać!

Ale w tym momencie dyskusja się kończy, a nie zaczyna, jako że Błażej Śliwiński należy do badaczy wykluczających tytuły prawne margrabiów do całego Pomorza. 


\section{List Mściwoja do margrabiów (1271) w okresie wojny domowej (1269-1272)}

Według źródeł oliwskich poddani Warcisława II bez jego wiedzy, czy on sam z pomoca baronów, latem 1269 r. uwięził własnego brata Mściwoja II w jakimś „Redzku”, uchodzącym pospolicie za Raciąz, co podtrzymuje na nowo Śliwiński ${ }^{36}$. Ale wnet wierni ludzie Mściwoja uwolnili go i wyprawiono się z sukcesem na Gdańsk, z którego Warcisław uszedł, tracąc księstwo ${ }^{37}$. W tym czasie (przed 17 stycznia $1270 \mathrm{r}$.) ziemię sławieńską zają Wisław II książę Rugii, korzystający - zdaniem Śliwińskiego - z aprobaty Barnima, który jako sojusznik Mściwoja i uzgodniony w 1264 r. jego sukcesor obawiał się Warcisława, a do tego narastał jego konflikt z margrabiami na tle zagarnięcia dóbr joannitów korytowskich (na tym tle klątwa nałożona na Barnima 12 sierpnia 1269 r.). Akcja Wisława ułatwiła Mściwojowi opanowanie Gdańska i wygnanie brata, który uciekł do Elbląga pod opiekę Krzyżaków, a następnie po chorobie zmarł w Wyszogrodzie (9 maja 1271 r.). Jakby przy okazji w wirze tych wydarzeń Mściwoj przed 20 lutego 1270 r. opanował jeszcze księstwo tczewskie stryja Sambora II. To jednak spowodowało groźną interwencję jego protektorów, braci zakonu krzyżackiego w Prusach ${ }^{38}$.

Zagrożony ze strony Krzyżaków, Mściwoj zwrócił się o pomoc do swych nowych panów lennych (,dominis suis”): margrabiów Jana II, Ottona IV i Konrada I. O przebiegu wstępnych rozmów i treści nowych deklaracji wobec nich dowiadujemy się z jego listu - znanego i tym razem z kopii - odnoszonego do roku 1271, raczej bliżej jego początku ${ }^{39}$. Znów przy nim zatrzymajmy się na czas jakiś.

Rozmowy prowadził „jego rycerz pan Ludwik” („militis nostri domini Lud.”) i za ustnym pośrednictwem tłumacza „pana” Henryka (,domino H. interpreti”) została złożona margrabiom atrakcyjna oferta negocjacyjna. Henryk powrócił z Ludwikiem z deklaracją margrabiów i wtedy książę polecił spisać ustalone warunki: swą prośbę za radą

36 MPH, t. 6, s. 313, 355; B. Śliwiński, Mściwoj II..., s. 133 et seq., gdzie przegląd źródeł, opinii lokalizacyjnych owego „Redzka” oraz datowania tych wydarzeń.

37 B. Śliwiński, Mściwoj II..., s. 139-142.

38 Ibidem, s. 142-162.

39 B. Śliwiński, Rola polityczna możnowtadztwa na Pomorzu Gdańskim w czasach Mściwoja II, Gdańsk 1987, s. 104; K. Jasiński, List Mściwoja II do margrabiów brandenburskich. Uwagi polemiczne i postulaty badawcze [w:] Pomorze słowiańskie $i$ jego sasiedzi, red. J. Hauziński, Gdańsk 1995, s. 31-43; G. Labuda, Historia Kaszubów w dziejach Pomorza, t. 1: Czasy średniowieczne, Gdańsk 2006, s. 270, datuje go na koniec 1270/początek 1271. 
rycerza Ludwika o pomoc św. Katarzynie, NMP, św. Mikołajowi i wszystkim świętym, patronom kościołów gdańskich, w zamian oferując na własność (,in proprietatem offerimus”) miasto, gród Gdańsk i ziemię gdańską ${ }^{40}$. Czyli „lekką ręka”, jak pisze Śliwiński, miał oddawać margrabiom to, co dopiero zdobył na bracie, zadowalając się dzielnicą świecką i ewentualnie tczewska! ${ }^{41}$

Dostrzegłem w tych negocjatorach rycerzy Wedlów, przybyszy z Holsztynu i do niedawna rozsiadłych w ziemi stargardzkiej pod władzą Barnima: Ludwika, lidera sześciu braci, i jego młodszego brata Henryka, w służbie Mściwoja od czasu jego pobytu w Reczu, który Wedlowie zagarnęli joannitom. Kiedyś wbrew wszystkim postawiłem bowiem na zamek w Reczu nad Ina, a nie na Raciąż jako miejsce uwięzienia Mściwoja za sprawa ludzi Warcisława II ${ }^{42}$. Do takiej propozycji zachęcał udział Wedlów w zagarnianiu dóbr cystersów kołbackich koło Choszczna, następnie ich wielki awans materialny właśnie w tej okolicy już pod władzą margrabiów, którzy ten teren przejęli, a co najważniejsze, ich udział w zajmowaniu Pomorza Gdańskiego przez margrabiów. Potem zostałem zmuszony zrezygnować z tego drugiego z braci, gdy zwrócono uwagę, że chodziło o tłumacza Henryka już wcześniej występującego 1 sierpnia 1267 r. podczas zjazdu braci Warcisława i Mściwoja w Świeciu dla zawierania pokoju z zakonem krzyżackim, ale przy czynności pierwszego z nich. Wystapił jako tłumacz stanu świeckiego, bo wśród świeckich funkcjonariuszy dworskich ${ }^{43}$. Do grona przeciwnych takiej identyfikacji tłumacza z 1271 r. dołączył kiedyś Kazimierz Jasiński, wątpiąc w udział Ludwika Wedla i proponując poprawienie zwrotu militis nostri na militis vestro, by uzyskać stan równowagi: mianowicie tylko po jednym przedstawicielu Mściwoja i margrabiów w tych rokowaniach z 1271 r. A taka możliwość mogła zaistnieć, ponieważ jest znana tylko kopia listu Mściwoja wykazująca opustkę jednego słowa ${ }^{44}$. Dlatego i Śliwiński uznał, że niczym

$40 \quad \mathrm{P}, \mathrm{nr} 250$.

41 J. Baszkiewicz, Odnowienie Królestwa Polskiego 1295-1320, Poznań 2008, s. 54.

42 E. Rymar, Walka o Pomorze..., s. 14-19; idem, Udział rodu Wedlów w ekspansji margrabiów brandenburskich na Pomorze Środkowe i Wschodnie w latach 1269-1313 [w:] Pomorze stowiańskie i jego sqsiedzi..., s. 46-48.

${ }^{43} \mathrm{P}, \mathrm{nr} 222$ („Heynrico interpreter”) i nie ma wątpliwości, że to osoba świecka, zatem z otoczenia Mściwoja, a nie Warcisława II, zob. B. Śliwiński, Mściwoj II..., s. 100,106

${ }_{44}$ P, nr 250, o Henryku K. Jasiński, List..., s. 33-35. 
już teraz nie jest potwierdzona hipoteza o służbie także Ludwika u Mściwoja ${ }^{45}$.

Opustka jednego słowa jest bez znaczenia - zresztą nie zaistniała odnośnie do kwestii rycerza Ludwika! Nadal opowiem się za Ludwikiem von Wedel jako mediatorem z upoważnienia Mściwoja, ale też i jego brata jako tłumacza-mediatora nie wykluczę. Henryk I von Wedel znany jest tylko ewentualnie z tych dokumentów $(1267,1271)$, ale był też 17 sierpnia $1272 \mathrm{r}$. przy margrabim Janie II w Lubece w związku z jego akcją zbrojna na Pomorzu Gdańskim, gdy po rycerzach, w tym Ludwiku Wedlu, jako świadkowie wystapili giermkowie (,famuli”): Jan von Altenfliess, Henryk Toyte - więc sołtys z Barlinka - i Heinricus de Wedele. Musi przecież zastanawiać podróż tych dwóch braci Wedlów $\mathrm{z}$ margrabiami do Lubeki w związku $\mathrm{z}$ ich poczynaniami tyczacymi Pomorza Nadwiślańskiego! Wystapił Henryk jeszcze 6 stycznia $1281 \mathrm{r}$. w Choszcznie przy margrabiach: Janie II, Ottonie IV, Konradzie. Brak go jednak już 25 kwietnia 1282 r., gdy w Chojnie czterej bracia Wedlowie, w tym najmłodszy Ludolf, sa świadkami ich czynności ${ }^{46}$. Zmarł więc w 1281/1282 r. Znajomość języka Pomorców mógł Henryk posiasść w dzieciństwie w rodzinnym otoczeniu w ziemi stargardzkiej. Kwestię Wedlów traktujmy tu jednak jako marginalna.

O wiele ważniejsza jest nowa interpretacja Błażeja Śliwińskiego treści listu. Wcześniej tłumaczono tak duży zakres ustępstw (oddawanie Gdańska i ziemi gdańskiej) skłonnością Mściwoja do nieszczerego koniunkturalizmu, ponieważ w istocie nie zamierzał przecież dopełnić dawanej obietnicy ${ }^{47}$. Zresztą i tak przejmowanie przez Askańczyków ziemi gdańskiej uważano za przejaw ich agresji, brutalnego parcia na wschód. Tylko właściwie piszący te słowa staną na gruncie ich legalizmu, od dawna bowiem traktował całe Pomorze jako obszar powierzony im w 1231 r. przez Rzeszę, zatem mieli prawo je uzależniać lub anektować ${ }^{48}$. Zdaniem Śliwińskiego natomiast zwrot w sprawie oferowania Gdańska i ziemi gdańskiej nie oznacza przekazania na własność, ale poddanie pod lenną zwierzchnośćc ${ }^{49}$. Do tego Mściwoj w 1283 i $1290 \mathrm{r}$.

$45 \quad$ B. Śliwiński, Mściwoj II..., s. 163.

46 CDBrand. B, Bd. 1, s. 116; Bd. 13, s. 221; Bd. 18, s. 2.

47 K. Jasiński [w:] Historia Gdańska..., t. 1, s. 292; idem, List..., s. 38

48 E. Rymar, Walka..., s. 28.

49 B. Śliwiński, Mściwoj II..., s. 164 i przyp. 27, gdzie przywołano dawniejsza literaturę traktująca decyzję księcia jako formę zapłaty za pomoc (zastaw). Lenno sugerował już S. Kujot, Margrabiowie..., s. 50 et seq.; P. Żmudzki, Studium podzielonego królestwa. Ksiażę Leszek Czarny, Warszawa 2000, s. 217; zwłaszcza E. Rymar, 
wspomniał o sądzeniu mieszczan gdańskich za zdradę, bo na jego zgubę połączyli się z margrabiami ${ }^{50}$, co byłoby niezrozumiałe, gdyby sam przekazywał Gdańsk margrabiom na własnośćc1.

Tymczasem margrabiowie posiadali już lenną zwierzchność nad Pomorzem i to od Rzeszy Niemieckiej, co dla stron było oczywistościa, bo książę legalizował akt raweński z 1231 r. już w 1269 r. w odniesieniu do księstwa świeckiego, podobnie jak wcześniej swymi hołdami Barnim I szczeciński i Warcisław III dymiński (1234/1236, 1250). Mściwoj wyraźnie zaoferował margrabiom ziemię gdańską i Gdańsk na własność (,in proprietatem offerimus”). Widocznie bez ich realnego użytkowania, bowiem potem oczekiwał, aby oddali mu je w lenno ${ }^{52}$.

Jednak margrabia Konrad, odpowiadając na propozycję Mściwoja II, mając przy tym wsparcie mieszkających w Gdańsku Lubeczan, latem 1271 r. interweniował zbrojnie na Pomorzu Gdańskim. Ku zaskoczeniu księcia pomorskiego margrabia zdecydował się na zatrzymanie Gdańska i przystapił do zajęcia ziemi gdańskiej. Zaskoczenie wynikało stąd, że po śmierci Warcisława II pomoc margrabiego nie była jego starszemu bratu potrzebna. Potem Mściwoj twierdził, że diabeł zasiał niezgodę między nimi, w domyśle: Niemcy z Pomorza, w tym z samego Gdańska, uznajacy Konrada za swego nowego pana terytorialnego, toteż do planowanego hołdu nie doszło, bo Mściwoj nawet nie spotkał się z Konradem ${ }^{53}$. Konrad trafił na opór rycerstwa, ludzi cystersów oliwskich i samego księcia powracajacego z Kujaw z pomoca Bolesława Pobożnego wielkopolskiego ${ }^{54}$. Nie widzę w tym czegoś niezwykłego. Podobnie margrabiowie postępowali już wcześniej na Pomorzu. Dla przykładu, po zajęciu terenów wokół Choszczna w 1269 r. wcale nie przekazali ich swemu lennikowi Barnimowi I, wcześniej wałczącemu o nie z Piastami wielkopolskimi. Potem jednak w 1278 r., dla pozyskania go w walce o stolec arcybiskupi w Magdeburgu dla margrabica Eryka, margrabia Konrad wydał mu tamże w lenno szmat ziemi pomorskiej między Iną i Małą Iną po Stargard, w tym wsie wydarte tam wcześniej cystersom kołbackim ${ }^{55}$. Nie

Walka..., s. 28; idem, Wielkie Pomorze..., s. 36; idem, Brandenburgia a Pomorze..., s. 52. O „ofercie lennej” pisał G. Labuda, Historia Kaszubów..., t. 1, s. 290.

$50 \mathrm{P}, \mathrm{nr} 365,464$.

51 B. Śliwiński, Mściwoj II..., s. 165.

52 Podobnie E. Rymar, Wielkie Pomorze..., s. 36; idem, Brandenburgia a Pomorze..., s. 52 .

53 B. Śliwiński, Mściwoj II..., s. 166.

54 Ibidem, s. 170.

55 PUB, Bd. 2, nr 1096; E. Rymar, Historia polityczna..., s. 187. 
musieli margrabiowie wydawać ziemi gdańskiej Mściwojowi w lenno, zwłaszcza gdy ewentualnie ów domniemany diabeł - czyli niemieckie mieszczaństwo Gdańska - im takie postępowanie podszepnął!

Śliwiński stawia na retorsję Mściwoja: lennik wobec zachowania się Konrada „uznał za niebyłe wszystkie swoje dotychczasowe układy z władcami Brandenburgii”, do czego miał prawo zgodnie z normami lennymi, gdy oni nie dochowali mu wierności. Odwołał więc Mściwoj i hołd choszczeński, i postanowienia w sprawie ziemi białogardzkiej. Nigdy też później margrabiowie „nie odwoływali się już do układu lennego z Choszczna, by skorzystać z przysługujących im praw zwierzchnich. Po 1271 nigdy też Mściwoj nie określał ich swymi panami lennymi i nigdy nie zatwierdzali jego nadań, co typowe dla seniorów"56. Jednak błąd tkwi w potraktowaniu Mściwoja jako równorzędnego partnera margrabiów, który zerwał wcześniejsze ustalenia, margrabiowie byli bowiem jakoby zobligowani do wzajemnych, porównywalnych wobec niego obowiązków, w tym owego „dochowywania wierności”.

Obligatoryjny - to (wedle słowników języka polskiego) obowiązujący, powinny, należny, konieczny; a obligować - to nakładać obowiązek, obarczać długiem wdzięczności; zobligować - to zobowiązać kogoś do czegoś, wywołać w kimś chęć odwzajemnienia otrzymanej przysługi ${ }^{57}$. Wywód Śliwińskiego opiera się na błędnych założeniach, ponieważ margrabiowie mieli tytuły prawne od Rzeszy, toteż nie byli do niczego „zobligowani’ przez deklaracje hołdownicze Mściwoja. Relacji Mściwoja wobec margrabiów nie można sprowadzać do znanej feudalnej relacji senior-wasal obligującej strony do wzajemności (tyle jest winien wasal seniorowi, ile senior wasalowi). Lenne zwierzchnictwo nad księstwem Mściwoja nie było rozciagane z jego inicjatywy, a trwało ciagle. Z tego tytułu margrabiowie sięgnęli w 1308 po byłe władztwo Mściwoja i w 1309 r. sprzedali Pomorze zakonowi krzyżackiemu. Korzystali więc jak najbardziej z przysługujących im praw zwierzchnich. Ono istniało z mocy (niemieckiego) prawa! Mściwoj nie mógł tego odwoływać, ale rzeczywiście po tych przykrych doświadczeniach mógł zadziałać wbrew wcześniejszym zobowiązaniom. Grzeszyć wszak można po rozgrzeszeniu i odprawieniu pokuty. Ale tu ponownie, jak wyżej, przy omawianiu

56 B. Śliwiński, Mściwoj II..., s. 192 et seq. W kwestii nieodwoływania się do układu choszczeńskiego też G. Labuda, Podstawy polityczno-prawne kupna Pomorza Gdańskiego..., s. 52.

57 Stownik wyrazów obcych PWN, red. J. Tokarski, Warszawa 1980, s. 52; Stownik jezyka polskiego, t. 3, red. M. Szymczak, Warszawa 1981, s. 1052. 
hołdu choszczeńskiego, tracimy grunt do dalszej dyskusji, gdy kwestionujemy - jak Śliwiński - działanie owego niemieckiego zwierzchniczego prawa margrabiów na Pomorzu po 1231 r.

W początkach 1272 r. na prośbę Mściwoja na Pomorze wkroczyły wojska Bolesława wielkopolskiego, niwecząc skutki interwencji brandenburskiej. Wiosna-latem 1272 r. wyparci z Pomorza Gdańskiego margrabiowie uwikłali się w wojnę z koalicja: arcybiskup Magdeburga, książęta Meklemburgii, hrabia Szwerynu, Wisław II z Rugii władający ziemia sławieńska. Do tego wojska wielkopolskie wkroczyły do byłej kasztelanii santockiej, spustoszyły Strzelce, przywracając zajęły zamek w Drezdenku z pomoca „pewnych Kaszubów”, zapewne podesłanych przez Barnima $\mathrm{I}^{58}$. Margrabiowie podjęli szeroko zakrojone zabiegi dyplomatyczne, aby osłabić impet przeciwników i pozyskać sojuszników. Margrabia Jan II, Otton IV i Konrad 17 sierpnia 1272 r. tytułem nagrody za dotychczasowe usługi w Lubece nadali lubeczanom wolność celną w Gdańsku, na Wiśle i na całej ziemi gdańskiej oraz zwolnienie od prawa brzegowego, co było konfirmacja takiego przywileju nadanego przez Warcisława II $^{59}$. Wedle Śliwińskiego wyraźnie tym aktem lubeckim margrabiowie dążyli do odnowienia kontaktów z Mściwojem, który zerwał zależności od nich. Widzi w nim próbę przywrócenia dawnych kompetencji i stosunków z księciem, zanim rozpamiętywanie niedawnego złamania wzajemnych relacji partnerskich przez Konrada (i braci) nie przerodzi się wraz z upływem czasu „w zapiekłą niechęć do margrabiów”, i w dalszym planie nadzieję na ponowienie ze strony Mściwoja zależności lennej z ziemi świeckiej, ale i wcześniej obiecywanej gdańskiej. Przywilej miał być świadectwem „ponownego układania się" margrabiów z Mściwojem ${ }^{60}$.

Trzeba było przecież jakoś wytłumaczyć zabiegi Lubeki o potwierdzenie jej praw celnych na Pomorzu oraz wystapienie margrabiów w roli panów tego Pomorza przy fatalnych stosunkach z tamtejszym władca. Dlatego badacz zmuszony jest wytłumaczyć meandry polityki księcia, który dopiero co pozbył się intruzów i po pół roku znów wejdzie w dawne buty, znów będzie się z nimi spotykał i układał, o czym zaraz niżej. Śliwiński chyba również zaplątał się w owym węźle gordyjskim, jakim dotąd jest dyplomacja Mściwoja II, by wytłumaczyć postawę margrabiów i Lubeki: widocznie o rokowaniach Mściwoja z margrabiami

\footnotetext{
58 B. Śliwiński, Mściwoj II..., s. 190-192.

$59 \mathrm{P}, \mathrm{nr} 254,255$.

60 B. Śliwiński, Mściwoj II..., s. 194.
} 
wiedzieli wszyscy. Wiedziała i Lubeka, że Mściwoj przez rokowania - które przecież są tylko domniemaniem badacza - miał publicznie przedstawić swój punkt widzenia na temat przyczyn zerwania dotychczasowego układu lennego z margrabiami. Inaczej: upublicznienie przez księcia przebiegu niedawnych spraw zamknęło margrabiom usta i „postawiło ich w sytuacji, w której wręcz niemożliwe było już podnoszenie przez nich przed autorytetami świata opartego na zasadach powiązań lennych jakichkolwiek pretensji do księcia wschodniopomorskiego", co było sukcesem dyplomacji Mściwoja. Margrabiowie w swym mniemaniu mogli nadal uważać się za zwierzchnika Mściwoja „ale zanim pamięć o tym, czego dopuścili się względem niego w 1271 r. nie zatarła się, nie mieli odwagi przywoływać aktu z Choszczna" 61.

Ileż tu komplikacji przy objaśnianiu spraw prostych!

Po rządach czeskich Przemyślidów (książąt Rzeszy) w 1308 r. margrabiowie zbrojni znów wkroczyli na teren Pomorza Gdańskiego, a ponownie stąd wyparci sprzedali w 1309 r. w Myśliborzu do niego prawa zakonowi krzyżackiemu, rzeczywiście nie odwołując się wcale do deklaracji czy hołdów Mściwoja, ale legalizując to na niemieckim dworze królewskim Henryka Luksemburga, bo dokonywali zbycia obszaru posiadanego z woli Rzeszy! Dla Śliwińskiego jest oczywiste odwołanie układu z Choszczna, a o jego poszerzeniu na ziemię gdańską czy słupską można mówić w formie „propozycji”. Opinię tę można wesprzeć przypomnieniem, że wcześniejsze tytuły prawne margrabiów do Pomorza, które uzyskali od władców Rzeszy Niemieckiej, także nie były brane pod uwage podczas transakcji przeprowadzonej przez margrabiów z Krzyżakami. Przecież Kujot, przywoływany tu przez Śliwińskiego, napisał o odwołaniu przez Mściwoja układu ${ }^{62}$, milczącym zrzeczeniu się margrabiów z korzyści danych mu przez układ w Choszcznie ${ }^{63}$. Trzeba bowiem było dopatrzyć się logiki w poczynaniach (meandrach?) polityki Mściwoja, który wszak w 1278 r. nawet wziął udział w wyprawie zbrojnej na ziemie margrabiów, w 1283 r. zbrojnie odzyskał ich kosztem ziemię sławieńską. Śliwiński wybrał tę opcję, wbrew wyrażonemu już wcześniej memu

61 Ibidem, s. 194.

62 S. Kujot, R. 20-23, s. 954.

63 S. Zachorowski, Wiek XIII i panowanie Władysława Eokietka [w:] Dzieje Polski średniowiecznej, cz. 1: Do roku 1333, Kraków 1920, s. 209. Podobnie układy z lat 1269-1273 za niebyłe uznali kiedyś m.in.: B. Włodarski, Świętopełk i Mściwój II, ZH 1968, t. 33, s. 85; K. Zielińska, Zjednoczenie..., s. 36, J. Spors, Dzieje..., s. 139. 
poglądowi, że hołd nie mógł być odwołany przez wasala ${ }^{64}$. Badacz ignoruje o wiele ważniejszy fakt mandatu zwierzchniczego Askańczyków. Postawa Mściwoja w danej sytuacji nie kasowała tych tytułów!

\section{Układ drawski (3 września 1273 r.)}

Drugim - wedle Śliwińskiego - powodem podjęcia przez Mściwoja na nowo rozmów z margrabiami była możliwość odzyskania z ich pomoca od księcia Rugii ziem słupskiej i sławieńskiej, co ma wynikać z dalszego biegu zdarzeń. Akcję przeciw Wisławowi II poprzedza obecność ludzi margrabiów: Waltera von Arnstein i Gunthera hrabiego von Dornburg latem 1273 r. w otoczeniu Mściwoja. W wyniku tego, jak się wydaje, aktem z 3 września 1273 r. na moście na Drawie (,actum et datum, in ponte Drawe”) Mściwoj II zrezygnował na rzecz swych panów (,dominorum nostrorum"), margrabiów: Jana, Ottona i Konrada, ze swych ziem (,castra et terras nostras”) słupskiej i sławieńskiej z przyległościami. Otrzymał je z powrotem od nich w lenno (,feodali titulo”). Po swojej śmierci pragnie ich dla swych dzieci (,nostris pueris”) w lenno, za wyjątkiem części zapisanej niegdyś swemu szwagrowi (,sororio nostro”), panu Henrykowi von Kirchberg. Mściwoj gwarantował sobie możliwość swobodnego czynienia tam w swej intencji nadań dla kościołów i klasztorów. Zobowiązał się margrabiom i ich dziedzicom w ciagu dziesięciu tygodni udzielać pomocy na wezwanie przeciw każdemu, wszakże wyłączając Bolesława (Pobożnego) wielkopolskiego, ale też z wyłączeniem jego ewentualnej akcji wymierzonej w margrabiów - wtedy Mściwoj miał wystapić przeciw Bolesławowi. Margrabiowie ze swej strony (,vice versa") przez dziesięć tygodni z panami Walterem von Arnstein i hrabią Güntherem von Dornburg obiecywali wsparcie Mściwojowi i jego dzieciom/synom. By wola księcia nie uległa zniekształceniu, została właśnie na moście tym spisana i opieczętowana (,Ut igitur predicta omnia a nobis [...] in perpetuum inviolabiliter observentur, presentem paginam conscribi fecimus et sigilli nostri munimire roborari”). Świadkami tej czynności byli: biskup kamieński Herman, rycerze Betekin von Bentz, Georgius/Jerzy i Dytryk von Kerkow, znany nam już Konrad von Kleist, Heidenryk von Bentz i wielu innych ${ }^{65}$. Dokument podobnie jak poprzednie pochodzi z kopiariusza brandenburskiego. Świadkowie - poza biskupem - pochodzą tylko

\footnotetext{
64 E. Rymar, Brandenburgia..., s. 52.
}

65 PUB, Bd. 2, nr 878; P, nr 256. 
$\mathrm{z}$ otoczenia margrabiów, inaczej jak w Choszcznie. Biorąc pod uwagę akt Konrada von Kleista z 7 kwietnia 1269 r., można by snuć wprawdzie domysł, że pozostawał w otoczeniu biskupa, jednak ostatni raz o tym byłym marszałku Barnima I wspomniano w akcie pokoju margrabiów z Bogusławem IV 13 sierpnia 1284 r., również wśród rycerstwa brandenburskiego ${ }^{66}$.

Do tak ważnego zjazdu mogło dojść na moście na północ od Drawna, koło miejscowości Laskoń i Jaworze, na zachód od Kalisza Pomorskiego ${ }^{67}$, na szlaku zwanym „via Marchionis” („droga margrabiów”) prowadzącym zza Odry na Pomorze Nadwiślańskie. Jednak nie jest wykluczone miejsce poniżej późniejszego miasta Drawska. W obecność margrabiów na tym moście przy spisywaniu dokumentu wątpił Hermann Krabbo. Nabycie lennego zwierzchnictwa nad tymi dwiema ziemiami wydawało mu się skromną korzyścia, którą margrabiowie wynieśli ze swych stosunków z Mściwojem, po świeżej utracie Gdańska, ale i ten zysk był pozorny, bo Wisław II rugijski zajęta ziemię sławieńską traktował jako swoja, bo dziedzicznie nabytą i zgłaszał do niej roszczenia, o czym dowiadujemy się 18 stycznia $1277 \mathrm{r} .^{68}$

Brak zgodnych interpretacji dokumentu. Znów, jak w przypadku omówionego listu do margrabiów, pisano o zdradzie Mściwoja, o „nieroztropnym kroku”69, o nielojalności wobec ratującego go niedawno Bolesława Pobożnego, flircie z margrabiami jako przejawie niewdzięczności wobec opiekuna i obrońcy, ${ }^{70}$, albo akt bagatelizowano jako epizod bez większych następstw ${ }^{71}$ itp. Sądzono bowiem, że doszło do realizacji tych naddrawskich postanowień, w tym hołdu.

66 PUB, Bd. 2, nr 1312.

67 Jak E. Rymar, Wtadcy... (2), s. 33; idem, Drawa jako rzeka graniczna $w$ XIIIXV wieku [w:] Z. Mieczkowski, Eqczy nas Drawa. Monografia rzeki, Drawsko Pomorskie 2019, s. 88. Wykluczam most usytuowany w rejonie późniejszych miast DrawskaZłocieńca (gdzie poszukiwała go m.in. K. Górska-Gołaska, Drawski most [w:] SHGP, cz. 1, s. 399, bo ten górny odcinek rzeki margrabiowie kontrolowali dopiero od $1296 \mathrm{r}$., z tym jednak, że most ów nie znajdował się we władztwie biskupa (!), co już jest dodatkiem Śliwińskiego (Mściwoj II..., s. 199), na jego odpowiedzialność, jako że i tego władztwa w zlewni Drawy nie znajdziemy!

68 H. Krabbo w: Regesten, Bd. 1, nr 1046.

69 S. Kujot, Margrabiowie brandenburscy $w$ dziejach Pomorza za księcia Mestwina II, RTNT 1878, t. 1, s. 54.

70 B. Zientara, Przemyst II [w:] Poczet królów i ksiażat polskich, red. A. Garlicki, wyd. 8, Warszawa 1998, s. 212; O. Żmudzki, Studium..., s. 237; B. Nowacki, Przemyst II. Odnowiciel Korony Polskiej (1257-1296), Kraków 2007, s. 65 et seq. Te i inne opinie zebrał B. Śliwiński, Mściwoj II..., s. 200.

71 K. Jasiński, Zapis..., s. 184. 
Uważam, że nie warto do tego powracać, bo ten „polski godnościowy punkt widzenia” odmawiał Mściwojowi nawet prawa do układania się z agresorami, a co dopiero do składania im hołdów! Nie wykluczając poglądu Śliwińskiego, nawet jakby nie zauważano, że książę traktuje już w pierwszym zdaniu margrabiów jako swych panów, zatem uznaje ich za swych prawnych zwierzchników! Kolejne hołdy niczego w tych relacjach nie zmieniaja, nie sa konieczne, ich brak nie narusza „dominium directum” margrabiów na Pomorzu.

Nie wyrażano też wątpliwości, że margrabiowie byli obecni na tym moście oraz że wykonano wymienione w akcie postanowienia. Tymczasem zdaniem Śliwińskiego Mściwoj miał te postanowione czy spisane propozycje podjać „po namyśle”72. Ten „namysł” w tak ważnych przecież kwestiach byłby konieczny, ale nie pochodzi ze znanego już nam źródła. Śliwiński i namysł ów jako konieczny zaraz wykluczył, bo jego zdaniem do żadnego hołdu z tych ziem nie doszło, a dokument jest tylko projektem i to przygotowanym przez stronę brandenburska! Gdzie tego dowody? Ano po pierwsze, chociaż wystawca aktu miał być Mściwoj, powołano na świadków tylko rycerzy brandenburskich, wyraźnie inaczej niż podczas hołdu choszczeńskiego, którego świadkami są tylko jego ludzie. Widocznie nie wiedziano nawet, w jakim towarzystwie pojawi się na moście. Po drugie, wpisano datę 3 września, a już 8 września, czyli po pięciu dniach, Mściwoj był w Świeciu nad Wisła, a margrabiowie $\mathrm{z}$ ich naddrawskim świadkiem Georgiusem von Kerkow byli w Werbellinie, czyli obecnymi drogami, albo w linii powietrznej, około 210 i $180 \mathrm{~km}$ od mostu, co musi oznaczać, że gdyby byli na tym moście, to by pędzili w tak odległe miejsca znad Drawy „na łeb na szyje”, niczym gońcy na rozstawionych koniach, margrabiowie co najmniej $51 \mathrm{~km}$, Mściwoj $41 \mathrm{~km}$ dziennie - w rzeczywistości chyba więcej - podczas gdy książę poruszał się z prędkościa średnio $23,4 \mathrm{~km}$ dziennie ${ }^{73}$. Do tego, ledwie schodząc z konia, Mściwoj 8 września w Świeciu miał opieczętować ten dokument i to samo mieli uczynić w Werbellinie margrabiowie, przemieszczając się „bez chwili przerwy i wytchnienia”74.

Śliwiński dzięki Krabbowi złapał wiatr historii w żagle, toteż stałem się łatwym obiektem frontalnej krytyki po to, by wyeliminować ten „układ drawski’ z grona faktów historycznych! Przypomniał, że i ja uznawałem wpierw obecność margrabiów „za niepewną”, potem

72 B. Śliwiński, Mściwoj II..., s. 199.

73 Ibidem, s. 201

74 Ibidem, s. 202. 
jednak uznałem ją za „pewną"75. Zmieniłem stanowisko, ponieważ przyjąłem, że ziemia pomorska była „wiecznym lennem” już od czasów karolińskich. Wedle Śliwińskiego poglądu tego nikt, oprócz mnie, nie podziela. Moje założenie, iż na moście drawskim faktycznie doszło do złożenia hołdu, także stało się pretekstem do postawienia mi zarzutu. Spotkałem się z krytyką również dlatego, że przyjąłem, iż Mściwoj II trzymał się mocno postanowień układu zawartego z margrabiami i nie chciał od nich odstapić, nawet gdy margrabiowie nie udzielili mu pomocy i sami stali się władcami na ziemi sławieńskiej i słupskiej ${ }^{76}$. „Obraz stosunków lennych Mściwoja z margrabiami kreślony ostatnio przez E. Rymara sprowadza się w gruncie rzeczy do tego, że zawsze łamali oni układy z Mściwojem, a ten za każdym razem dawał się nabierać na nowe obietnice, później zaś łagodnie jak owieczka zgadzał się z sytuacja, dalej tkwiąc w nic mu niedającej zależności. Jest to obraz nieprawdziwy, wynikający z ogólnego, ale właśnie sztucznego przekonania badacza, że raz oddane w lenno ziemie musiały nawet przez setki lat zachowywać taki właśnie status"77.

Ponieważ rycerz von Kerkow był w Werbellinie i na moście, to jest wykluczone wystawienie dokumentu 8 września przez dwóch braci margrabiego, podczas gdy trzeci byłby obecny nad Drawa. Jałowa wokół tego byłaby dyskusja z powodu właśnie von Kerkowa. Dzień 3 września byłby chyba dniem kulminacyjnym spotkania, podczas gdy hołd wymaga ceremoniału, z biesiada, uroczystym pożegnaniem, a to wyklucza pośpiech, hołdowanie tuż na wyjezdnym! Należy więc wykluczyć złożenie hołdu i to na moście (również ewentualnie zastępcom margrabiów, upełnomocnionym hrabiom) ${ }^{78}$, bo takiej ujmy książę by nie zaakceptował, a „zaocznie” hołdowanie też należy wykluczyć. Zatem Śliwiński wyklucza i obecność Mściwoja na tym moście. Strony miały wymienić się „tylko propozycjami”, ale „do niczego więcej nie doszło”, m.in. „hołd pozostał tylko na papierze" i odpada twierdzenie, jakoby hołd miał teraz juz dotyczyć całego Pomorza Wschodniego, bowiem Rymar „nie potrafił uzasadnić prawa margrabiów do ziemi tczewskiej, uciekając się do hipotezy, że w czasie wojny domowej hołd margrabiom złożył

75 E. Rymar, Wtadcy... (1), s. 33; (2), s. 25.

76 Przywołujac moje słowa z rozprawy: Brandenburgia a Pomorze Gdańskie do poczatków XIV wieku..., s. 52.

77 B. Śliwiński, Mściwoj II..., s. 201, przyp. 41.

78 Bowiem upełnomocnienie hrabiów Arnsteina i Dornburga do zawarcia układu kiedyś dopuszczałem (Władcy... (1), s. 33). 
także i Sambor II (ale kiedy i jak, już nie wyjaśnił) ${ }^{79}$. Tymczasem Mściwoj w początku lat siedemdziesiątych w ogóle nie był lennikiem margrabiów z żadnej ziemi's0.

Podjęta wyżej poboczna kwestia dotycząca dzielnicy tczewskiej nie została należycie zaprezentowana. W przywołanej przez mego polemistę rozprawie (zob. przyp. 80) napisałem: „Istnieją też źródłowe przesłanki przypuszczenia, że podczas tej gdańskiej ekspedycji brandenburskiej, zawiedziony w swych nadziejach na powrót do dzielnicy tczewskiej z pomocą Krzyżaków, lennikiem margrabiów został Sambor, ujęty potem w Gdańsku przez interweniujących Bolesława i Mściwoja”. Rzeczywiście, czytelnik nie dowiaduje się tam, jakie są te „źródłowe przesłanki”. Ale przecież w odsyłaczu odesłano do rozprawy z 1987 r., w której usiłowałem - może nieudolnie czy niewystarczajacco - ten hołd uprawdopodobnić na przełomie 1271/1272 r., kiedy to Sambor przebywał w Gdańsku, który zajęły wojska margrabiego Konrada. Pisałem tam: „Wiadomo, że [Sambor] to poplecznik i sojusznik zakonu krzyżackiego. Mógł być wówczas zawiedziony w swych nadziejach na powrót do dzielnicy wobec wycofania się zakonu 31 października 1271 r. układem z Bolesławem Pobożnym z walk na Kujawach. Dopasować do tego przypuszczenia można pogląd [...], że w tym mniej więcej czasie, a nie później, Mściwoj ugodził się z Krzyżakami, odstępując im posiadłości w ziemi gniewskiej, świeckiej i nowskiej, co dokumentuja źródła z 1276 i 1282 r. W latach 1272-1276 pozycja Mściwoja na Pomorzu nie była zagrożona, więc chyba wówczas nie musiał z niczego rezygnować na rzecz Krzyżaków. Dlatego Sambor mógł wejść w porozumienie z margrabią Konradem, by z jego pomoca, prawdopodobnie jako przyszły lennik, wrócić do Tczewa" ${ }^{\text {" }}$.

Śliwiński zgromadził argumenty za zajęciem przez Mściwoja dzielnicy tczewskiej przed 10 lutego 1270 r. ${ }^{82}$, co było równoznaczne ze zjednoczeniem całego Pomorza Wschodniego, wobec tego, skąd to wykluczanie zhołdowania przez margrabiów Mściwoja z całego Pomorza Wschodniego, za czym się już dawno opowiedziałem? Mściwoj uznał zwierzchnictwo nad sobą w 1269 r. i obejmowało ono automatycznie poszerzony stan jego posiadania na Pomorzu, bo całe było objęte „dominium directum” Askańczyków.

\footnotetext{
Jakoby E. Rymar, Wielkie Pomorze..., s. 37.

80 B. Śliwiński, Mściwoj II..., s. 202 et seq. i przyp. 47.

81 E. Rymar, Walka o Pomorze Gdańskie..., s. 28 et seq.

82 B. Śliwiński, Mściwoj II..., s. 151 et seq.
} 
Powracając do głównego nurtu, streszczę dalszy ciag rozważań Śliwińskiego, według którego spotkanie na moście drawskim było tylko planowane i strony wiedziały o nim przed 3 września 1273 r., ale tam się nie wybierały, skoro 8 września przebywały w tak odległych miejscach (Werbellin, Świecie). Mściwoj po odwołaniu układu choszczeńskiego, w związu z zachowaniem margrabiów w $1271 \mathrm{r}$., nieufnie zaledwie przedłożył propozycję w ramach ewentualnie zaplanowanej wspólnej akcji przeciw Wisławowi II, by pozbawić go ziem sławieńskiej i słupskiej, i dlatego przygotowano projekt wieńczący sukces hołdem. To zatem jedynie próba ułożenia stosunków z Mściwojem. Po doświadczeniach związanych ze złamaniem zasad w 1269 i 1271 r. Mściwoj, nie chcąc do końca zrażać do siebie margrabiów, obiecał im hołd pod warunkiem uzyskania od nich pomocy. Prowadził więc grę dyplomatyczna, podobnie jak margrabiowie, którzy doprowadzając w listopadzie 1273 r. do małżeństwa swej siostry Agnieszki z Erykiem Klippingiem duńskim, synem Małgorzaty Samborówny wschodniopomorskiej, widocznie rewanżowali się Mściwojowi możliwościa wniesienia na forum publicznym pretensji Sambora do bezprawnie zajętego księstwa tczewskiego. Te plany Mściwoja i margrabiów pozostały martwą litera. Nie wyszły poza wstępne ustalenia, stały się znów nieaktualne wobec tego małżeństwa i do wyprawy przeciw Wisławowi nie doszło! ${ }^{83}$

Trudno pojąć, co tu ważniejsze, miejsce pobytu stron po pięciu dniach od 3 września, czy też inne o wiele ważniejsze względy i projekty? Ten wyjściowy czy podstawowy łatwo uchylić, badajacc znane itineraria. Gdańszczanin Daniel Chodowiecki w podróży z Berlina do Gdańska w 1773 r., by nawiedzić matkę, skrupulatnie odnotowywał czas przejazdu od świtu po zmrok i nocleg. Wyjechał konno z Berlina 3 czerwca rano o 7.00 i przez Werneuchen (tu obiad do 15.00) - przez Lemberg (17.00) dotarł o 20.00 do miasta Freienwalde, w którym zanocował. Jest to około $56 \mathrm{~km}$. Następnego dnia wyjechał z Freienwalde po śniadaniu o 5.50, pokonał promem Odrę, a o 11.00 dotarł do Chojny, skąd po obiedzie i odpoczynku wyjechał o 15.30, aby osiagnąć miasteczko Banie o 19.00 i o 20.00 zatrzymać się na nocleg w zajeździe w niedalekiej wsi Parnica. To około 65 km. I jeszcze prześledźmy peregrynację 5 czerwca. Z Parnicy wyruszył o 5.00, Pyrzyce (to około $12 \mathrm{~km}$ ) osiagną o 8.30, tu kawę wypił, konia kazał podkuć, a pytany przez napotkanego generała (ciagnącego pieszo z wojskiem),

$83 \quad$ Ibidem, s. 204. 
ile dziennie mil pokonuje, odparł, że 6-7. Po dwugodzinnym postoju w Pyrzycach osiagną Stargard około 15.00 (to około $22 \mathrm{~km}$ ), ale część drogi pokonywał pieszo, ponieważ koń nie chciał biec truchtem. O 17.30 Chodowiecki wyjechał, by tego dnia dotrzeć do Maszewa ${ }^{84}$. Razem to $60 \mathrm{~km}$. I tak podobnie w kolejnych dniach, pokonywał wcale nie „co koń wyskoczy”, ale co najwyżej truchtem, a nawet pieszo albo pisząc listy i poszukując poczty, pokonywał $50-65 \mathrm{~km}$ dziennie! Mściwoj po załatwieniu spraw nad Drawą nie mógł dziennie przemierzać $41 \mathrm{~km}$, mając ewentualnie do dyspozycji konie na zmianę? Kto w to poza Śliwińskim uwierzy?

Ale może na trzynastowieczne możliwości podróżowania odrobinę światła rzucą przykłady podróży, które odbyły się mniej więcej w tym samym czasie. Książę Barnim I 5 stycznia 1274 r. był w Dyminie, następnego dnia już w Ückermunde (Wkryujście), a to jest $72 \mathrm{~km}$. Margrabia Waldemar 22 sierpnia 1315 r. był w Dankowie i tego samego dnia w Gorzowie, co dokumentował spisana czynnościa prawna ${ }^{85}$, w odległości $24 \mathrm{~km}$ w linii powietrznej. Tenże 22 stycznia $1319 \mathrm{r}$. był w Barnewitz, na wschód od Rathenow nad Hawela, 24 stycznia w Linum, na południowy wschód od Fehrbellin w Ostprignitz (32 km), 26 stycznia w Spandau (40 km); 20 marca 1319 r. był w Tangermünde, 23 marca w Grünenberg, dokonując tu czynności na rzecz mieszczan Gorzowa $^{86}$. Nie była to chyba jednak dzisiejsza wieś Skrzynka koło Lipian czy Golice koło Cedyni. Wieś o tej nazwie jest też w Mittelmark na południowy wschód od Löwenberg, $120 \mathrm{~km}$ od Tangermünde. Jeszcze bardziej na wschód leży wspomniana w 1320 r. Groneberhe, na południe od Werbellina, oraz opuszczona wieś o takiej nazwie na północny zachód od miasta Eberswalde. W piątek 25 maja 1319 r. Waldemar był w Angermünde, Zielone Święta w niedzielę 27 maja spędzał już w Eberswalde, do którego przybył widocznie w sobotę, w poniedziałek

84 Daniela Chodowieckiego dziennik podróży do Gdańska z 1773 r., oprac. M. Paszylka, Gdańsk 2002, s. 2-3; zob. też ostatnio: A. Krywalewicz, Daniel Chodowiecki w drodze do Gdańska przez Nowa Marchię i Pomorze (1773), „Rocznik Chojeński” 2018, t. 9, s. 229 et seg.

85 PUB, nr 4109; CDBrand. A, Bd. 18, s. 214. Jeśli margrabiowie joanniccy byli 3 III 1297 (a nie 12 II 1296, bo taka możliwość jest rozważana) w Dobiegniewie, to przemieścili się stąd za Odrę koło Cedyni-Osinowa Dolnego, a potem na północ do wkrzańskiego Prenzlau, gdzie byli 8 III 1297 r., a więc około 180-200 km, przebywając średnio około 30-40 km dziennie (T. Jurek, Brandenburski zabór w Wielkopolsce 1296 r. Zapoznany dokument, „Studia z Dziejów Średniowiecza” 2004, nr 14, s. 364-365). W podobnym tempie zatem przemieszczali się nasi monarchowie w $1273 \mathrm{r}$.

86 CDBrand. A, Bd. 8, s. 218; Bd. 9; s. 15; Bd. 5, s. 67-8; Regesten, Bd. 1, nr 2680. 
28 maja był w Spandau, odległym od Eberswalde w linii powietrznej o $55 \mathrm{~km}^{87}$. Już takie dane osłabiają wyliczenia Śliwińskiego. W XVIII w. dziennie konno pokonywano $60-65 \mathrm{~km}$, nie urządzając przecież wyścigów, ale stępem (100 metrów/minutę). Obecnie mamy jeszcze bardziej optymistyczne wyliczenia odnośnie do XV w. Wójt Nowej Marchii wysłał gońca ze Świdwina 14 czerwca 1409 r. o godz. 22.00, który przez CzarneChojnice dotarł do Gniewa 18 czerwca o godz. 6.00, czyli pokonał około $210 \mathrm{~km}$ w 80 godzin; goniec krzyżacki wysłany 20 sierpnia $1422 \mathrm{r}$. o godzinie 20.00 ze Strzeczony (4 km na północ od Debrzna) w komturstwie człuchowskim, przez Starogard dotarł do Gniewa 23 sierpnia o 13.00 , pokonując $116 \mathrm{~km} \mathrm{w} 65$ godzin, a wysłany 30 lipca $1422 \mathrm{r}$. o 19.00 z Zamartego (12 km na południowy wschód od Człuchowa) przez Świecie, Grudziądz dotarł do Bratian już 1 sierpnia o 12.00 po 41 godzinach, pokonując ponad $203 \mathrm{~km}$, co daje dziennie $100 \mathrm{~km}$ ! Książę mazowiecki Janusz I Starszy (1381-1429) w dwa dni pokonał trasę $180 \mathrm{~km}$ z Łomży do Wyszogrodu. Dodam jeszcze niedawne ustalenia H. v. Seggerna dla Europy Zachodniej, według których posłańcy na drodze lądowej pokonywali wówczas nawet około $100 \mathrm{~km} \mathrm{dziennie}$. $^{88}$. To przy rozstawionych koniach, ale przecież księcia Mściwoja II stać było na to podczas dyplomatycznych podróży, tak do Choszczna (1269), jak i na most na Drawie (1273).

Ale nie to jest najważniejsze, zwłaszcza że może rzeczywiście „drawski układ” to wyłącznie spisany przez Brandenburczyków projekt? Tylko wtedy nie budzi jakoś zaufania „fakt” owego listu Mściwoja do margrabiów z 1271 r., pochodzącego z kancelarii brandenburskiej, i akt hołdu choszczeńskiego. Czyżby obecność Jerzego von Kerkow i grafa Guntera von Arnstein jako ewentualnych dowódców oddziałów brandenburskich w służbie Mściwoja II była w tym „projekcie” tylko planem(?). Tracę orientację, gdzie strona brandenburska wysmażyła ten dokument na imię Mściwoja, wybierając sobie do tego pewien most na rzece Drawie i dorzucając obecność na nim biskupa kamieńskiego Hermana! Po co? Dlaczego?

87 Regesten, Bd. 1, nr 2699-2701.

88 R. Simiński, Konflikt - pojednanie - wspótpraca. Studia nad polityka ksiażat zachodniopomorskich i biskupów kamieńskich wobec zakonu krzyżackiego $w$ Prusach w latach 1320-1423, Wrocław 2019, s. 541; M. Wilska, Mazowieckie środowisko dworskie Janusza Starszego. Studium społeczne, Warszawa 2012, s. 23; H. v. Seggern, Herrschermedien im Spätmittelalter. Studien zur Informationsübermittlung im burgundischen Staat unter Karl der Kühnen, Ostfildern 2003 (= Kieler Historische Studien 41), s. 107. 
Nie dostrzegam istotnych różnic tego aktu z podobnym aktem choszczeńskim Mściwoja, poza świadkami: tu brandenburscy, tam pomorscy z otoczenia księcia! Pochodzenie świadków nie może stanowić, że akt ten był zaledwie projektem kancelaryjnym spisanym nie w konkretnym celu, ale tylko na ewentualny użytek. Także w akcie choszczeńskim nic nie wskazuje na obecność margrabiów, ale tego Śliwiński nie podnosił! Zreszta, co ważniejsze, w samą istotę pomysłów Śliwińskiego odnośnie do interpretacji omawianych tu trzech aktów kancelaryjnych powstałych w relacjach Mściwoj II-Askańczycy brandenburscy (w szczególności trzeciego) godzi ważna wskazówka rodem z kancelarii brandenburskiej: wszystkie one zostały odnotowane w jej regestrze dokumentów wpływających, sporządzonym w $1336 \mathrm{r}^{89}$, a zatem bez wątpienia powstały poza kancelarią Askańczyków ${ }^{90}$.

Tak więc po raz trzeci i ostatni wypadnie stwierdzić, że Mściwoj nikogo i tym razem nie zdradzał, nie był nielojalny wobec wielkopolskiego krewniaka, nie flirtował czy układał się nieodpowiedzialnie z margrabiami agresorami, lecz rozciagał swe ewentualne przyszłe władztwo na ziemię sławieńską i słupska, już poza księstwa wschodniopomorskie z lenniczym błogosławieństwem tychże. Ceremonia hołdownicza nie była konieczna. Te relacje regulował stan prawny wprowadzony aktem raweńskim Rzeszy Niemieckiej i cesarza Fryderyka II w grudniu $1231 \mathrm{r}$. Na wieść o śmierci Mściwoja II (25 grudnia $1294 \mathrm{r}$.) margrabiowie natychmiast przypomnieli stan prawny, komu należało, na Pomorzu i wokół niego. Na prośbę braci Ottona IV ze Strzałą i Konrada ówczesny król niemiecki Adolf nassauski już 8 stycznia 1295 r. potwierdził im i odnowił w Mühlhausen raweński dokument w sprawie nadania ich ojcu Janowi I w lenno „ducatus Pomeranie"91! Przecież i tym razem chodziło o Pomorze Nadwiślańskie rządzone dotąd przez księcia Mściwoja II $^{92}$. Rozwój wydarzeń, jak zbrodnia rogozińska (luty 1296 r., widocznie w związku z objęciem przez Przemysła II wielkopolskiego schedy po Mściwoju), rządy czeskie od 1300 r. (gdy legalizował je najwyraźniej tylko na Pomorzu polskim Przemyślidom król niemiecki Albrecht z Habsburga

89 H. Bier, Das Urkundenwesen und die Kanzlei der Markgrafen von Brandenburg aus dem Hause Wittelsbach 1323-1373, Bd. 1, Berlin 1907, s. 28, przyp. 4.

90 Na co zwrócili mi uwagę redaktorzy merytoryczni „Studiów z Dziejów Średniowiecza”, za co serdecznie dziękuję.

91 CDBrand. B, Bd. 1, s. 210.

92 O czym więcej E. Rymar, Brandenburgia a Pomorze Gdańskie do poczatków XIV wieku..., s. 53 et seq. 
nadający Wacławowi II w lenno ziemie okupowane dotąd - jak to określił - przez księcia Władysława Łokietka!) do 1306 r., powodował, że dopiero w 1308 r. margrabiowie ponownie sięgnęli po Gdańsk oraz jego bliższe i dalsze pomorskie okolice.

\section{Abstract \\ Mestwin II as a vassal of Brandenburg margraves (in the years 1269-1273)}

In the paper, the author enters into a comprehensive polemic with the assertions of Błażej Śliwiński contained in his monograph on the Duke of Gdańsk Mestwin II regarding his relations with Brandenburg margraves. Once again he is attempting to substantiate his view that the feudal relation of Mestwin II to the margraves had earlier, Carolingian roots. Other detailed issues related to the policy of the Gdańsk duke regarding Brandenburg are also discussed in the paper. 